\title{
Integration of Content Instruction and Language Instruction in the Movie English Classroom: On the Basis of Embodiment, Image Schemas, and Metaphors
}

\section{Im, Mijin ${ }^{1}$}

\begin{abstract}
The purpose of this paper is to suggest a method to integrate both content instruction and language instruction when a teacher uses a movie in an EFL classroom. In order to do this, three concepts were used: embodiment, image schemas, and metaphors. The film Love, Rosie (Ditter, 2014) was chosen, with 4 scenes from the movie analyzed in terms of embodiment, image schemas, and metaphors. The results indicate that there are possibilities to integrate the two instructions harmoniously. First, each utterance consists of concrete concepts and abstract ones. In particular, abstract concepts are explained by way of concrete ones, which naturally allows learners to understand a movie script easily. Second, image schemas can be an appropriate tool to see through the degree of intensity of characters' emotional states. This phenomenon makes learners understand relationships among characters and consequently enjoy the whole movie story. Third, learners can have a special experience with language learning. Embodiment, image schemas, and metaphors allow learners to see the language based on meaning, leading to enjoyment. Fourth, analysis of utterances in this paper based on the three concepts show how the salience of language pieces can be enhanced. In conclusion, a teacher can realize how to deal with content and language in the Movie English classroom with this approach.
\end{abstract}

Keywords: embodiment, image schemas, metaphors, Love, Rosie, EFL

Applicable level: tertiary

\footnotetext{
${ }^{1}$ Corresponding author, Assistant Professor, Graduate School of Education, Kookmin University, 77 Jeongneung-ro, Seongbukgu, Seoul, 02707, Korea (E-mail: immijin@kookmin.ac.kr)

Received: April 10, 2021

Revised: May 18, 2021

Accepted: May 23, 2021

Copyright: (C) 2021 The Society for Teaching English through Media (STEM)

This is an open access article distributed under the terms of the Creative Commons Attribution Non-Commercial License (http://creativecommons.org/licenses/by-nc/4.0), which permits unrestricted non-commercial use, distribution, and reproduction in any medium, provided the original work is properly cited.
} 


\section{INTRODUCTION}

Movies are attractive to people because they have stories. When they are imported into the EFL classroom, EFL teachers face a big challenge about how to instruct movie content and language harmoniously. Yet, the recent development of YouTube successfully manages to answer the concern about language issues through movies. For example, one popular YouTuber, Gusulsam (n.d.), shows four expressions ${ }^{1}$ using a movie context to aid her instruction in each of her videos. Her delivery is very good in that she spends a very short time explaining each expression with the relevant movie clip, and consequently, EFL learners do not feel bored by her lecture. This fact is crucial as many digital learners do not like spending a long time with one topic.

The goal of this paper is to suggest a classroom approach that is like Gusulsam's. One challenge to accomplishing this is understanding the difference in the ratio of content and language that is presented. Currently, movie stories are used in colleges and universities because they emphasize a liberal education, and they should not be ignored. Thus, it can be said that movie English follows content-based language teaching (CBLT) (Nassaji \& Kartchava, 2019; Villalobos, 2014; Wesche, 2012). More specifically, Nassaji and Kartchava call CBLT "two for one pedagogical approach" (p. 597). That is, the primary concern in CBLT is content, and the secondary is linguistic form. Moreover, it emphasizes the use of content and attention to linguistic forms simultaneously, while it seems that YouTube puts slightly more focus on language rather than content. Therefore, this paper will show a more balanced way of content and language instructions.

To accomplish this, three concepts of embodiment, image schemas, and metaphors will be used. Embodiment refers to the idea that the body matters to the mind (Bergen, 2015). Gibbs (2017) says many aspects of language and thought are related to bodily experience in one way or the other. In other words, our cognition is influenced by our experiences in the physical world (McNerney, 2011). McNerney gives us a very interesting example about this. When somebody says that something is "over our heads," it means that something is too difficult to understand. To express this meaning, part of our body, the head, is used. Thus, when they try to express an abstract idea, they metaphorically mention visible and concrete things for the abstract idea, and when these visible and concrete things are related to the human body, it is called embodiment. Emotion is another aspect to understand all thought, meaning, and action of human beings (Brown, 2007). Emotion and human cognition are deeply related to each other (Carr, Kever, \& Winkielman, 2018), so emotion should not be ignored in order to understand human cognition (Phelps, 2006). Putting this together, embodiment functions for difficult concepts to move from concreteness to abstractness. Embodiment, image schemas, and metaphors are concepts to express humans' emotion which is connected to embodied cognition (Ziemke \& Lowe, 2009).

In this paper, a movie is used as material. Characters in the movie emotionally interact by themselves, so they are very cautious or sensitive to use appropriate language to protect themselves from opponents or to cheer others up. Automatically their utterances reflect embodied cognition or grounded cognition ${ }^{2}$ (Barsalou, 2008, 2010) which emphasizes the interaction of characters and their environment (Goodwin, 2003). These are well expressed in a movie script. Accordingly, it is a good breakthrough to analyze movie utterances in terms of embodiment, image schemas, and metaphors. Ultimately, allowing EFL classrooms to enjoy both a movie story and embodied language.

\section{LITERATURE REVIEW}

\section{Embodiment}

If we roughly define embodiment, it refers to the idea about how the mind relates to the body (Bergen, 2015; Gibbs, 2003). This is enough for the purpose of this paper, which is to find the embodied richness of a language. Language processing is a process of "perspective taking" (MacWhinney, 2008, p. 214). Perspective is a subjective point of view,

\footnotetext{
${ }^{1}$ The four expressions are "you read my mind," "don't push it," "glad to hear that," and "that's all I can ask for."

2 Embodied cognition and grounded cognition are considered as the same concepts. Borghi and Pecher (2011) bind the two concepts as one and call them "the embodied and ground approach." They say that this approach "proposes that cognitive activity is grounded in sensory-motor processes and situated in specific contexts and situations" (p. 1).
} 
and human language is not a device to express only the real world (Menn, 1997). Through perspectives, humans only show who they are. Therefore, the term perspective is essential to understand embodiment.

MacWhinney (2008) shows four perspectival systems: "(1) affordances, (2) spatio-temporal reference frames, (3) causal action chains, and (4) social roles" (p. 215). Yet, this paper does not deal with those perspectives due to a lack of space. However, an example of the first perspective, affordances, is introduced with his favorite example of "banana." MacWhinney (2008) says that affordances are sensations that people feel when they manipulate, for example, a banana. When it is touched with their hands, they feel the texture of the banana peel. If people look at the banana, they perceive the yellow and brown colors of the banana. Then haptic affordances and visual ones are coordinated. In this way, much information about the banana is accumulated. In addition, languages show the embodied nature of object name affordances. People speak of, "the hands of a clock, the teeth of a zipper, and the foot of the mountain" (MacWhinney, 2008, p. 220). The next narrative will show how the mind relates to the body. It has been written by Sandra to her fiancé, Barry.

I know that I shouldn't be so naive about this sort of thing, but when he presented me with a draft of the agreement, it was so formal and legal and felt so cold to me that I just broke down crying. I simply couldn't stand to see our future relationship be reduced to questions of money. [my underline] It seemed like Barry didn't trust me, or that he lacked faith in our future. I had always thought that we were in this together, going forward as partners as we started dating, got serious, then engaged, and hopefully soon married. [my underline] Now my parents want me to consult with a lawyer to insure I don't get screwed by the pre-nup. (Gibbs, 2005, p. 1)

Let us examine the first underlined utterance. A closer look at what Sandra says, we can observe that embodied experiences support the narrative. Sandra is shocked to see her relationship with Berry depends on a money issue. In particular, she uses "stand" to express how she feels about the money issue. "Stand" is a part of the human body action, so this is a typical embodiment. The second utterance seems more complicated, but the basic idea is the same as the first one. Sandra expresses the first moment to start dating as "going forward." It is like they set out on a trip. The second destination is "getting serious." To express physical bodily movement, they continue to travel to a particular state, "getting serious." Finally, they will arrive at the final destination of marriage. These stages are all related to embodiment.

\section{Image Schema}

One difficult issue is to understand the nature of complex concepts and events, but humans seem to be able to overcome such challenges with little thought or effort (Hedblom, Kutz, Peñaloza, \& Guizzardi, 2019). How do they do this? They understand concepts and events based on their experiences. Image schemas help this understanding. When humans face simple or complex events repeatedly, such experience is cognitively structured through the mental structure called image schemas (Johnson, 1987; Lakoff, 1987).

Image schemas are abstract representations of perceptual and kinetic experience (Grady, 2005). That is to suggest that they come from bodily experience, in the sense that perception and kinetics belong to the human body. However, "image" of image schemas should not be considered as too specific things around the world or the environment. They are mental representations associated with broad classes of concepts or experiences. The following is Lakoff (1987)'s description of image schemas:

Image schemas are relatively simple structures that constantly recur in our everyday bodily experience: CONTAINERS, PATHS, LINKS, FORCES, BALANCE, and in various orientations and relations: UPDOWN, FRONTBACK, PART-WHOLE, CENTER-PERIPHERY, etc. (p. 267)

When you read the above description, image schemas are roughly described, not in full detail. For example, a container is not too specific. Simply it only shows a sort of idea that is divided into "in" or "out." It does not give us any more information about a real container. 
Image schemas are an important term to understand the relationship between the conceptual system and physical experience in the world. Also, they play an essential role to learn children's acquisition of concepts, which are directly related to their language acquisition. Mandler (2012) mentions that "preverbal infants develop an extensive conceptual system during the first year of life" (p. 421). This conceptual system is expressed in language (Mandler, 2004). Some concepts in this conceptual system must be preverbal because these stimulate language acquisition. Thus, image schemas help language acquisition development occur.

Moreover, image schemas are spatial representations that express conceptual meanings or primitives. Though they reflect conceptual meanings, they are basically preconceived structures (Hampe, 2005). Also, they are simple spatial stories from spatial primitives (Mandler \& Pagán Cánovas, 2014).

Lastly, for a better understanding of image schemas, let us analyze the example expression, "Don't get your hopes up." Analyzing this case through image schemas, one can start by identifying "hopes" as an abstract concept that is not a moving object. On the contrary, the preposition "up" is used with a moving thing, so how are they combined together? They are semantically conflicted. VERTICALITY image schema intervenes between them and helps "up" to go together with "hopes." In this way, image schemas complete embodiment.

\section{Metaphor}

Another concept which implements embodiment is a metaphor. It may be better to start with Sfard (1998).

All our concepts and beliefs have their roots in a limited number of fundamental ideas [my italic] that cross disciplinary boundaries and are carried from one domain to another [my italic] by the language we use. (p. 5)

[Metaphors] often cross the borders between the spontaneous and the scientific, between the intuitive and the formal. (p. 4)

Let us think about "a limited number of fundamental ideas" by considering why do we need to restrict our concepts or beliefs within the limits of fundamental ideas? Put simply, if the concepts or beliefs cannot be restricted within the limitation, our language should express them without limitation. Then, we need some new vocabulary to cover limitlessness. Yet, we cannot learn a language just because new vocabulary is infinite. Mandler (2005) says that learnability is one of the constraints to learn a language. In other words, constraints prevent us from going to infinity and help human beings to learn a language without much effort.

Then if a language has a certain limitation and constraints, how can we express ideas freely? The answer is the use of metaphor. Next is Kövecses (2010)'s description of the role of metaphor.

[...] speakers of English make extensive use of the domain of journey to think about the highly abstract and elusive concept of life. The question is: Why do they draw so heavily on the domain of journey in their effort to comprehend life? Cognitive linguists suggest that they do so because thinking about the abstract concept of life is facilitated by the more concrete concept of journey. (pp. 3-4)

According to Kövecses (2010), the abstract concept of life is expressed by the concrete concept of journey. The concrete word "journey" has more than one meaning, that is, a polysemous word to overcome the limitation. This is called metaphor. Casasanto and Gijssels (2015) assert that the concrete concept of journey is the source domain and the abstract concept of life is the target domain. These kinds of metaphors are called embodied metaphors (Kompa, 2017; Wang et al., 2019).

Furthermore, when metaphors appeared as the main concern to cognitive linguistics, they existed as metaphorical language. Kövecses (2010) distinguishes conceptual metaphor from metaphorical linguistic expressions. However, in the 21 st century, metaphors are weighed more deeply than ever. When people do not use metaphorical language, they think metaphorically (Casasanto \& Bottini, 2014; Casasanto \& Gijssels, 2015). Casasanto and Bottini (2014) ask a question about how people think of abstract entities. The answer is that people think in spatial metaphors. For example, prices are expressed as "high" or "low." However, not all people think in the same way, with some people 
finding a close relationship between metaphorical language and metaphorical thinking, while others do not show such a relationship. Nevertheless, current research about metaphor will not be mentioned anymore. Instead, for this paper, it is enough to introduce what metaphor means and what kind of roles metaphor play.

\section{METHOD}

\section{Goal}

The goal of this paper is to look for a successful way of teaching Movie English with a focus on content and language forms simultaneously. Since movies have charming stories to enjoy, teachers and students need to keep such stories alive in the EFL classroom. However, they need to remember not to ignore teaching nor learning the language.

How can they expect to enjoy movies and learning language forms in the classroom? This paper is investigating how it can be achieved through the concept of embodiment, image schemas, metaphors, and emotion. Human beings are doing bodily experiences in their daily lives. Such experiences influence their use of language. Emotion ${ }^{3}$ is also pervasive in human beings' lives. It is always expressed in their interaction, so it needs embodiment, image schemas, and metaphors to express emotional intensity. To this end, this paper analyzes utterances based on emotion and finds embodiment, particularly image schemas and metaphors in such utterances.

\section{Material}

In this paper, the 2014 romantic comedy film, Love, Rosie (Ditter, 2014) is going to be used. The movie is full of emotional disturbances appropriate to the goal of this paper. The main characters, Alex and Rosie, have emotionally experienced that they are not meant to be. They happen to grow up together from a young age. On Rosie's 18th birthday, Alex kissed her, but she did not remember the kiss because she was drunk at that moment. Furthermore, Rosie did not want to remember the day because she had her stomach pumped. She told Alex that she regretted the event, which led to Alex misunderstanding Rosie's words, and he was emotionally disappointed in her. Specifically, he thought that Rosie would only consider him as a friend, not as a boyfriend. This was the first disappointing event for Alex. After that, there were some more events that saddened him, and there were some incidents that affected Rosie. Due to this dynamic, conversations between Alex and Rosie will be the primary focus for analysis.

However, another important character is Rosie's father, who makes her feel comfortable and motivates her to do whatever she wants to do. Rosie feels peaceful after talking with her father. Additionally, Greg is Rosie's husband, and he often makes her feel outraged. As demonstrated, it is these emotional ups and downs of the movie, which is why Love, Rosie was selected for this paper.

\section{Procedure}

A simple procedure is used for this paper. First, four scenes are randomly chosen. Second, several metaphorical linguistic expressions are also selected for each scene. However, since there are so many metaphorical expressions in this movie, it would be unlikely that the teacher could introduce them all. Instead, 4 or 5 expressions will be randomly introduced. Third, each expression is going to be analyzed in terms of embodiment, image schemas, and metaphors. Fourth, the analysis will occur under the story background.

\footnotetext{
${ }^{3}$ If you are interested in emotion, please read Cherry (2020) and Celeghin, Diano, Bagnis, Viola, and Tamietto (2017). Cherry (2020) explains the 6 types of basic emotions. Basic emotions are a sort of primary emotions which consist of fear, anger, joy, sadness, surprise, and disgust (Celeghin et al., 2017). Basic emotions produce more emotions to form different feelings.
} 


\section{RESULT AND ANALYSIS}

\section{Alex's Letter}

(Rosie decides separation with Greg and rearranges her house. In the middle of cleaning, she found Alex's letter in the Greg's drawer.)

Letter: Rosie, you deserve someone who loves you with every beat of his heart. Someone who will always be there for you, and who will love every part of you, especially your flaws. I know Katie needs her dad. I don't want to intrude. So if this is all wrong, just ignore it and I promise I'll never broach the

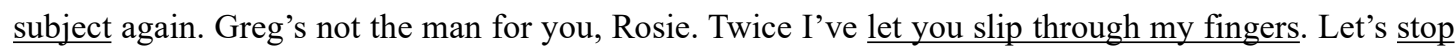
being afraid and take the chance. I know now I can make you happy. Call me if you feel the same way. Love, Alex.

(Conversation 1, Love, Rosie)

\section{1) Context}

This letter was written by Alex at the airport when leaving for Boston. Alex had visited England from Boston to attend Rosie's father's funeral. It was during this trip that he had met Rosie and her husband, Greg. He was disheartened by Greg's bad behavior at the funeral and worried about Rosie's future. Moreover, at that time, Alex had ended his relationship with Sally due to her cheating. Therefore, if Rosie had wanted to live with him, he would be willing to accept her.

\section{2) Analysis}

There were 7 underlined parts that turn abstract concepts into bodily actions. Let us start with "every beat of his heart." "With every beat of his heart" means sincerely. The former uses a part of the human's body (heart) for "sincerely." Alex is expressing his sincerity to Rosie through the letter. This is one instance of embodiment.

Next, let us consider every part of you. If you read the next words, "flaw," "every part of you" includes "flaws," "strength," etc. Therefore, the physical part (every part) reflects the abstract concept "flaws." This is embodiment, too.

The next example "broach" means "opening something physically". "The subject" cannot be open because it is not a thing like a container with a lid. "Let you slip through my fingers" is another instance where concreteness is combined with the abstract. Think of trying to grasp something slippery like a fish. This would easily "slip through your fingers" and escape if you don't hold it firmly. The chance is the fish (metaphorically), so if you lose the fish, you (metaphorically) lose the chance. The real object "fish" chance" is interesting because the word "stop" is related to "a moving thing." Yet, "being afraid" is not a moving thing. Instead, the word relates to emotion, and emotion is an abstract entity, which makes this another example of an embodiment.

In "take the chance," the verb "take" refers to the meaning "hold." As already noted, "chance" is a word that can be used metaphorically. Thus, while "chance" is not an object, in this example, it can be regarded as a concrete entity. Finally, looking at "make you happy," the verb "make" is like "make" of "make a box." It is used abstractly with the adjective "happy."

In sum, the above seven phrases are all language pieces to combine a part of the body or movement with abstractness. These are all instances of embodiment. Thus, Alex has written a letter to Rosie, changing his heart to concrete entities.

\section{Rosie's Congratulatory Speech}

(Rosie says a few words at the reception congratulating Alex)

Rosie: Final word of warning. Alex can hold his drink to an almost lethal degree, as I discovered on my 18 th birthday, when he decided a night of tequila slammers was the way to go. Whoo! Well, you know 
when people say that they were so drunk, that the whole night is a blank and you always go, "No way, not possible." Well, believe me, it's possible.

(The guests laugh) (pause)

Rosie: Choosing a... Choosing the person that you want to share your life with is one of the most important decisions any of us makes, ever. Because when it's wrong, it turns your life to grey. And sometimes... Sometimes you don't even notice until you wake up one morning and realize years have gone by. We both know about that one, Alex. Your friendship has brought glorious Technicolor to my life. It's been there even in the darkest of times. And I am the luckiest person alive for that gift. I hope I didn't take it for granted. I think maybe I did. Because sometimes you don't see that the best thing that's ever happened to you is sitting there, right under your nose. But that's fine, too. It really is. Because I've realized that no matter where you are or what you're doing, or who you're with, I will always honestly, truly, completely love you. Like a sister loves a brother and a friend loves a friend. I'll always stand guard over your dreams, Alex. No matter how weird or twisted they get. So, please, everybody, join me in a toast. To the bride and groom.

Guests: To the bride and groom!

(Conversation 2, Love, Rosie)

\section{1) Context}

Now Rosie is saying a few words at a reception congratulating Alex. Alex is getting married to Bethany, who is a supermodel. Earlier, when Rosie and Bethany had happened to meet at a hotel, Rosie gave her a tip about Alex: he lives in Boston and misses old friends. This advice had helped Bethany get married to Alex, and she appreciated it so much that she had proposed that Rosie be Alex's best man at the wedding, even though she is a woman.

\section{2) Analysis}

(1) "hold his drink": To be able to drink a large amount of alcohol without getting drunk

The verb "hold" is commonly used as "grab a thing." Yet, in this context, "hold" is used differently. If Alex keeps holding his drink, he should not get drunk. In this case, "hold" is used metaphorically. Furthermore, it represents that Alex is very strong at drinking alcohol. Thus, if Rosie drinks the same amount of alcohol, it is not surprising that she would lose consciousness and could not remember kissing Alex.

(2) "share your life with someone"

"Life" is not a thing, so it cannot be split up. Rosie embodies the abstract entity, "life," using the verb "share."

(3) "turns your life to grey" and "technicolor"

Rosie regards life through colors. She uses "color" as the source domain and "life" as the target domain. Thus, the instance where "life is a color" is expressed is an image of schema.

\section{(4) "years have gone by"}

Here, Rosie regards time (= years) as movement. She uses "gone by" as the source domain and "years" as the target domain. To Rosie, her time goes too fast, and she regrets not choosing Alex in her past life. This is an instance of a metaphor.

\section{(5) "the darkest of times"}

Rosie primarily uses time as a color (e.g., TIME IS COLOR). Then she extends this phrase to PAIN IS DARK. She uses two different conceptual metaphors, which are examples of image schemas.

\section{(6) "right under your nose"}

Rosie likens "near" to "under your nose." In this instance, the body is considered as "closeness." It is a good 
example of showing the character's regret at missing her best chance to stay with Alex through embodiment.

\section{(7) "in a toast"}

Rosie uses "toast" as container/containment. Containment image schema is used in this scene, as the preposition "in" refers to a dynamic state. In other words, trajector walks into the container gallantly (Cervel, 1998-1999). Therefore, when she makes a toast, she does this gallantly and sincerely.

To sum up, there are more examples of embodiment and metaphorical language in the sample. Yet, there are even more samples that can be taken from the scene and others. Thus, by combining the movie's story with its metaphorical language, teachers can teach both content and language enjoyably.

\section{Conversation Between Rosie and Alex}

Rosie: Pathetic.

Alex: She's mine for the taking.

Rosie: You're lucky she didn't trip over your tongue dragging halfway across the ground.

Alex: Whoa. Okay. All right. Well, give me some tips then, if you are so clever. How do I go about seducing a woman who is apparently out of my league?

Rosie: Is that a serious question?

Alex: Yeah, absolutely.

Rosie: Mmm, well, you're at a disadvantage being a, you know, (whispers) virgin.

(Conversation 3, Love, Rosie)

\section{1) Context}

This dialogue between Alex and Rosie seems short, but its impact is massive as they grow apart from one another for a long time. In the scene, they are sitting on the bench and talking about their upcoming school dance. Rosie obviously wants to go to it with Alex, but he feels differently. He still cannot forget about their kiss on Rosie's 18th birthday, yet she cannot remember the kiss due to being heavily intoxicated. This makes Alex feel like she is not interested in being his girlfriend. The conversation becomes awkward because they are talking about their senior prom, where it is common for young people to invite the person they are interested in. Unfortunately, Rosie thinks that Alex would be her escort, but he hopes that Bethany will be his date. Rosie is shocked but does not stop him from going with the other girl.

\section{2) Analysis}

\section{(1) "trip over your tongue dragging halfway across the ground"}

Rosie is making fun of Alex, who is embarrassed by Bethany's offer for their school dance. She depicts his pathetic behavior with a turgid expression, "dragging halfway across the ground." Obviously, it is understood that nobody can drag their tongue on the ground, but even though we have never physically experienced this, we understand Rosie's intention. How? The answer is from Robbins and Aydede (2009), who say that "not all forms of embodiment involve bodily dependence" (p. 5). Then how can embodiment be achieved without bodily dependence? Simulation is the answer. According to embodied perspective on concepts, cognition is influenced by the grounded properties of the environment by simulations or by bodily states (Gallese \& Lakoff, 2005; Kaschak, Jones, Carranza, \& Fox, 2014; Kompa, 2017; Scorolli, 2014). The result is Rosie's exaggerating expression is a form of embodiment.

\section{(2) "give me some tips"}

In this example, Alex wants Rosie's advice to seduce Bethany. For this, he uses a ditransitive construction which links the verb, "give," with three arguments. First, the agent of a transfer is deleted; second, one is a recipient; and third, one is a transferred object. Thus, the transferred object should be a thing, but "some tips" is an abstract concept 
instead of a thing. Moreover, the basic meaning of "give" is extended to an abstract concept and conveys the idea of a physical transfer, which makes it a metaphor. Last, "give" presupposes transfer. All this together shows that Alex really wants advice from Rosie.

\section{(3) "out of my league"}

Bethany is the most beautiful girl in school, so Alex is overwhelmed by her reputation. Now a compound preposition, out of, is CONTAINER schema, which Cervel (1998-1999, p. 266) demonstrates with a diagram in Figure 1.

\section{FIGURE 1}

A TR Outside an LM

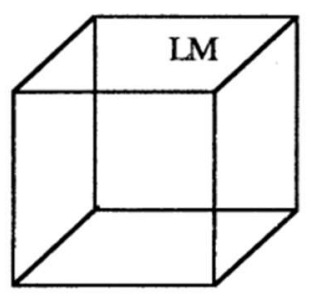

TR

Note. $\mathrm{LM}=$ landmark, $\mathrm{TR}=$ trajectory; From "The prepositions in and out and the trajector-landmark distinction" by M. Cervel, 1998-1999, RESLA, 13, pp. 261-271. Retrieved from https://ialnet.unirioja.es/servlet/articulo?codigo=227015

TR is the highlighted entity, and LM simply serves as a reference point for the TR (Cervel, 1998-1999). If a TR is out of an LM, the former is not influenced anymore by the latter because the TR becomes detached from LM (Cervel, 1998-1999). Back to the scene, based on Alex's quote, Bethany is out of his league. In other words, she is completely independent of Alex's world, and she is not controlled by him. Using the CONTAINER schema, we better understand that the social status of the two characters is very different. This explanation shows that "out of" is an image schema.

\section{(4) "at a disadvantage"}

Rosie is teasing Alex because he has no experience with sexual relations. If one wants to understand "at a disadvantage" visually, they must start with the meaning of the preposition "at." "At" is considered a general place preposition but is also referred to as a "neutral place preposition." Therefore, the preposition "at" indicates a place as a point of orientation, ignoring its physical shape. Dirven (1993) gives an excellent example of the disregarding of physical shape. When we say, "at the station," other people do not know whether "the trajector is near, inside, or on top of the station area" (p. 74). Furthermore, Song (2013) cautiously says that English may be a language of prepositions. In fact, one can see English prepositions used in a variety of ways. Case in point, in the example of "at the desk," "at" can be understood as close to the desk. However, "at the desk" can also mean "performing a characteristic action, like studying or writing" (Swanepoel, 1998, p. 660). In the scene, the word "at" in "at a disadvantage" is a metaphorical orientation point. Yet, this dialogue is given without background information about Alex. Therefore, when Rosie says to Alex, "you are at a disadvantage," it means nothing. It doesn't scare Alex at all. This is what "at" tells us.

This section demonstrates that embodiment includes image schemas and metaphors while also making the movie story more visual and detailed. Moreover, such concepts show us how characters in the movie respond emotionally.

\section{Rosie's Dad's Letter}

(Rosie is reading her dad's letter)

Dad: Dear Rosie, I can't believe it. Here I am at last, finally walking the Mediterranean coast. I've lost count of the years I've waited for this moment. Somehow life got in the way. And it was all good, I don't regret a minute of it, but we forget our dreams at our peril. I know you had yours, too, and it must feel sometimes like they're gone for good. But I'm so proud of the woman you've become, Rosie, of the 
mother you've been to Katie. What I once said about you is still true, there's nothing you can't do if you put your mind to it. So keep chasing those dreams, will you, darling? For my sake, Dad.

(Conversation 4, Love, Rosie)

\section{1) Context}

Rosie's elderly parents had gone on a journey to the Mediterranean, but sadly, her father died while visiting Nice, Italy. Before he died, he sent a letter to Rosie. He knew Rosie had experienced a sad life because her marriage was unsuccessful, and she had to give up her future because she gave birth to an unexpected baby. In the past, he had always given her strength to survive in the real world, and in this scene, she is reading her father's final letter.

\section{2) Analysis}

\section{(1) "lost count of the years"}

The verb "lost" means that you do not have something anymore. Something is a physical thing, while "count" is an abstract concept and not a physical thing. Thus, it is a metaphor.

\section{(2) "waited for this moment"}

"Wait for" means expecting someone or something that moves. Yet, "this moment" is not a moving entity, which makes this a metaphor, too.

\section{(3) "life got in the way"}

Dad admits parts of his life were like huge walls or obstacles he had to overcome. This is another metaphorical linguistic expression that implies that her Dad had a hard time during his life.

\section{(4) "a minute of it"}

Dad says he has never regretted his life even though it often prevented him from what he wanted to do. He regards his life minute by minute. That is, LIFE IS A TIME for him. It is an image schema.

\section{(5) "you put our mind to it"}

The basic meaning of "put" is to move something into position. "Our mind" cannot be a movable thing. Therefore, this is an image schema: MIND IS A MOVABLE THING. Dad encourages Rosie to keep moving forward for herself through the image schema.

\section{(6) "chasing those dreams"}

"Chase" is typically used to describe to hunt someone or something, which is physically moving entities. Dream is not a moving thing. Like "you put our mind to it" DREAM IS A MOVABLE THING. It is an image schema.

In summary, while only six phrases were selected, many more examples exist in this scene. Therefore, this helps to showcase that language is metaphorical in nature and that many of the utterances of this movie are metaphorical.

In total, analyzing the four scenes of the movie has highlighted that people use language metaphorically often. Moreover, emotion tends to stimulate people to express themselves beyond the literal meaning of language. Since people and emotion are inseparable, metaphorical linguistic expressions always stay with them. From the pedagogical perspective, embodiment, metaphor, and image schemas are helpful to understand what people are trying to say. Those concepts tend to make the abstract concepts into concrete concepts. Through this, students can enjoy the movie story better and learn metaphorical linguistic expressions a lot. 


\section{CONCLUSION}

Instructed SLA is divided into language focused instruction and content focused instruction. Specifically speaking, focus-on-form (FonF) instruction, focus-on-forms instruction, and focus-on-meaning instruction are three different types of instruction in L2 classrooms (Long, 1991; Ollerhead \& Oosthuizen, 2005). Among them, focus on forms instruction is exclusively language-based, and focus on meaning is exclusively meaning-based. That is why current interest draws upon focus-on-form instruction. Focus-on-form instruction is defined as "brief attention to linguistic elements as they arose spontaneously" (Loewen, 2011, p. 579).

FonF seems similar to language-based instruction in this paper, but it is different in two ways. First, spending time is different. FonF instruction spends a relatively short time on language matters compared to this paper because the primary concern of FonF is content. On the contrary, the primary concern in this paper is both content (movie stories) and language (embodiment). Second, language matters of FonF are not fun at all, but language matters in this paper are enjoyable.

This paper picks a movie in order to analyze utterances. While it is true that utterances in movies are not real life, they can still be a study tool to help students to understand simple and complex language concepts. The movie Love, Rosie shows various emotional ups and downs among characters. Moreover, because the physiology of emotion is related to embodied experience (McNerney, 2011), emotion is important to understand embodiment.

This paper observes how emotional changes are expressed in language. For the observation, four scenes ${ }^{4}$ were randomly selected, and many embodied utterances were found. It was realized that human beings express their ideas depending on bodily experience. As already mentioned in section 4, the utterance, "years have gone by" includes embodiment. The time concept "years" cannot move because it is not a moving thing. However, Rosie, who emotionally regretted her passing life, unconsciously combined "time" with "movement." This made Rosie regret everything that could have been more deeply.

Suppose a teacher gives their students language instruction with embodiment. For example, if learners are asked to analyze the language of the dialogue explaining Rosie's feelings about her past life, the result could be that teacher's instruction would enhance the salience of the relevant words. Consequently, EFL students can find themselves enjoying the content while learning the language simultaneously.

Lastly, there's a pedagogical implication for teachers who use Movie English in the EFL classrooms. Movie storytelling and language instruction should be done together in the same domain. If movie stories go this way and language instruction goes that way, students might feel pressure to pay attention to both content and language.

\section{REFERENCES}

Barsalou, L. W. (2008). Grounded cognition. Annual Review of Psychology, 59, 617-645. https://doi.org/10.1146/annurev.psych.59.103006.093639

Barsalou, L. W. (2010). Grounded cognition: Past, present, and future. Topics in Cognitive Science, 2(4), 716-724. https://doi.org/10.1111/j.1756-8765.2010.01115.x

Bergen, B. (2015). Embodiment. In E. Dabrowska \& D. Divjak (Eds.), Handbook of cognitive linguistics (pp. 10-30). Berlin, Germany: de Gruyter Mouton.

Borghi, A. M., \& Pecher, D. (2011). Introduction to the specific topic embodied and grounded cognition. Frontiers in Psychology, 2, Article 187. https://doi.org/10.3389/fpsyg.2011.00187

Brown, H. D. (2007). Principles of language learning and teaching. White Plains, NY: Pearson Longman.

Carr, E. W., Kever, A., \& Winkielman, P. (2018). Embodiment of emotion and its situated nature. In A. Newen, L. D. Bruin, \& S. Gallagher (Eds.), The Oxford handbook of $4 E$ cognition. https://doi.org/10.1093/oxfordhb/9780198735410.013.30

Casasanto, D., \& Bottini, R. (2014). Spatial language and abstract concepts. WIREs Cognitive Science, 5(2), 139-149. https://doi.org/10.1002/wcs.1271

\footnotetext{
${ }^{4}$ For convenience sake, a script of the movie was divided scene by scene.
} 
Casasanto, D., \& Gijssels, T. (2015). What makes a metaphor an embodied metaphor. Linguistics Vanguard, 1(1), 327-337. https://doi.org/10.1515/lingvan-2014-1015

Celeghin, A., Diano, M., Bagnis, A., Viola, M., \& Tamietto, M. (2017). Basic emotions in human neuroscience: Neuroimaging and beyond. Frontiers in Psychology, 8, article 1432. https://doi.org/10.3389/fpsyg.2017.01432

Cervel, M. (1998-1999). The prepositions in and out and the trajector-landmark distinction. RESLA, 13, $261-271$.

Cherry, K. (2020). The 6 types of basic emotions and their effect on human behavior. Verywell Mind. Retrieved from https://www.verywellmind.com/an-overview-of-the-types-of-emotions-4163976

Dirven, R. (1993). Dividing up physical and mental space into conceptual categories by means of English prepositions. In C. Zelinsky-Wibbelt (Ed.), The semantics of prepositions: From mental processing to natural language processing (pp. 73-97). Berlin, Germany: do Gruyter Mouton.

Ditter, C. (Director). (2014). Love, Rosie [Motion picture]. United Kingdom: Constantin Film.

Gallese, V., \& Lakoff, G. (2005). The brain's concepts: The role of the sensory-motor system in conceptual knowledge. Cognitive Neuropsychology, 22(3), 455-479. https://doi.org/10.1080/02643290442000310

Gibbs Jr., R. W. (2003). Embodied experience and linguistic meaning. Brain and Language, 84(1), 1-15. https://doi.org/10.1016/s0093-934x(02)00517-5

Gibbs Jr., R. W. (2005). Embodiment and cognitive science. Cambridge, UK: Cambridge University Press.

Gibbs Jr., R. W. (2017). Embodiment. In B. Dancygier (Ed.), The Cambridge handbook of cognitive linguistics (pp. 449-462). Cambridge, UK: Cambridge University Press. https://doi.org/10.1017/9781316339732.028

Goodwin, C. (2003). The body in action. In J. Coupland \& R. Gwyn (Eds.), Discourse, the body, and identity (pp. 19-42). London: Palgrave Macmillan. https://doi.org/10.1057/9781403918543_2

Grady, J. E. (2005). Image schemas and perception: Refining a definition. In B. Hampe (Ed.), From perception to meaning: Image schemas in cognitive linguistics (pp. 35-55). Berlin, Germany: de Gruyter Mouton.

Gusulsam. (n.d.). [YouTube Channel]. Retrieved from https://www.youtube.com/channel/UC7k5xDVLrRNQMrdl NHx8IQQ

Hampe, B. (2005). Image schemas in cognitive linguistics: Introduction. In B. Hampe (Ed.), From perception to meaning: Image schemas in cognitive linguistics (pp. 1-14). Berlin, Germany: de Gruyter Mouton.

Hedblom, M. M., Kutz, O., Peñaloza, R., \& Guizzardi, G. (2019). Image schema combinations and complex events. KI-Künstlicche Intelligenz, 33, 279-291. https://doi.org/10.1007/s13218-019-00605-1

Johnson, M. (1987). The body in the mind: The bodily basis of meaning, imagination, and reason. Chicago, IL: The University of Chicago Press.

Kaschak, M. P., Jones, J. L., Carranza, J., \& Fox, M. R. (2014). Embodiment and language comprehension. In L. Shapiro (Ed.), The Routledge handbook of embodied cognition (pp. 118-126). London: Routledge.

Kompa, N. (2017). The myth of embodied metaphor. Croatian Journal of Philosophy, 17(50), 195-210.

Kövecses, Z. (2010). Metaphor: A practical introduction. Oxford: Oxford University Press.

Lakoff, G. (1987). Women, fire, and dangerous things: What categories reveal about the mind. Chicago, IL: The University of Chicago Press.

Loewen, S. (2011). Focus on form. In E. Hinkel (Ed.), Handbook of research in second language teaching and learning (Vol. II, pp. 576-592). New York, NY: Routledge.

Long, M. H. (1991). Focus on form: A design feature in language teaching methodology. In K. de Bot, R. Ginsberg, \& C. Kramsch (Eds.), Foreign language research in cross-cultural perspective (pp. 39-52). Amsterdam, The Netherlands: John Benjamins.

MacWhinney, B. (1999/2008). The emergence of language from embodiment. In B. MacWhinney (Ed.), The emergence of language (pp. 213-256). Mahwah, NJ: Lawrence Erlbaum.

Mandler, J. M. (2004). The foundations of mind: Origins of conceptual thought. Oxford, UK: Oxford University Press.

Mandler, J. M. (2005). How to build a baby III: Image-schema and the transition to verbal thought. In B. Hampe (Ed.), From perception to meaning: Image schemas in cognitive linguistics (pp. 137-163). Berlin, Germany: de Gruyter Mouton.

Mandler, J. M. (2012). On the spatial foundations of the conceptual system and its enrichment. Cognitive Science, 36, 421-451. https://doi.org/10.1111/j.1551-6709.2012.01241.x 
Mandler, J. M., \& Pagán Cánovas, C. (2014). On defining image schemas. Language and Cognition, 6(4), 510-532. https://doi.org/10.1017/langcog.2014.14

McNerney, S. (2011, November 4). Brief guide to embodied cognition: Why you are not your brain [Blog post] Retrieved from https://blogs.scientificamerican.com/guest-blog/a-brief-guide-to-embodied-cognition-whyyou-are-not-your-brain/

Menn, L. (1997). Evidence children use: Learnability and the acquisition of morphology. In M. L. Juge \& J. L. Moxley (Eds.), Proceedings of the 22nd Annual Meeting of the Berkeley Linguistic Society (pp. 481-497). Berkeley, CA: Linguistics Department.

Nassaji, H., \& Kartchava, E. (2019). Content-based L2 teaching. In J. Schwieter \& A. Benati (Eds.), The Cambridge handbook of language learning (pp. 597-620). Cambridge, UK: Cambridge University Press. https://doi.org/10.1017/9781108333603.026

Ollerhead, S., \& Oosthuizen, J. (2005). Meaning-focused vs form-focused L2 instruction: Implications for writing educational materials for South African learners of English. Stellenbosch Papers in Linguistics, 36, 59-84. https://doi.org/10.5774/36-0-13

Phelps, E. A. (2006). Emotion and cognition: Insights from studies of the human amygdala. Annual Review of Psychology, 57, 27-53. https://doi.org/10.1146/annurev.psych.56.091103.070234

Robbins, P., \& Aydede, M. (2009). A short primer on situated cognition. In P. Robbins \& M. Aydede (Eds.), The Cambridge handbook of situated cognition (pp. 3-10). Cambridge, UK: Cambridge University Press.

Scorolli, C. (2014). Embodiment and language. In L. Shapiro (Ed.), The Routledge handbook of embodied cognition (pp. 127-138). London: Routledge.

Sfard, A. (1998). On two metaphors for learning and dangers of choosing just one. Educational Researcher, 27(2), 413. https://doi.org/10.2307/1176193

Song, X. (2013). A cognitive linguistic approach to teaching English prepositions (Unpublished doctoral dissertation). University of Koblenz-Landau, Germany.

Swanepoel, P. (1998). Back to basics: Prepositions, schema theory, and the explanatory function of the dictionary. In T. Fontenelle, P. Hiligsmann, A. Michiels, A. Moulin, \& S. Theissen (Eds.), Proceedings of the 8th EURALEX International Congress (pp. 655-666). Liège, Belgium: Euralex.

Villalobos, O. B. (2014). Content-based instruction: A relevant approach of language teaching. Innovaciones Educativas, 15(20), 71-83. https://doi.org/10.22458/ie.v15i20.515

Wang, X., He, Y., Lu, K., Deng, C., Qiao, X., \& Hao, N. (2019). How does the embodied metaphor affect creative thinking? NeuroImage, 202, Article 116114. https://doi.org/10.1016/j.neuroimage.2019.116114

Wesche, M. B. (2012). Content-based second language instruction. In R. B. Kaplan (Ed.), The Oxford handbook of applied linguistics ( $2^{\text {nd }}$ ed., pp.1-22). Oxford, UK: Oxford University Press. https://doi.org/ 10.1093/oxfordhb/9780195384253.013.0019

Ziemke, T., \& Lowe, R. (2009). On the role of emotion in embodied cognitive architectures: From organisms to robots. Cognitive Computation, 1(1), 104-117. https://doi.org/10.1007/s12559-009-9012-0 